\title{
LOKALIŲ CENTRŲ VIETA IR VAIDMUO HIERARCHINĖJE DIDMIESČIO CENTRŲ SISTEMOJE: VILNIAUS PAVYZDYS
}

\author{
Justinas Bučys \\ Urbanistikos katedra, Vilniaus Gedimino technikos universitetas, \\ Pylimo g. 26/Traku g. 1, 01132 Vilnius, Lietuva \\ El.paštasJustinas.Bucys@vgtu.lt \\ Iteikta 20100329
}

\begin{abstract}
Santrauka. Vienas iš svarbiausių veiksnių, darančių itaką didmiesčio funkcionavimo kokybei, yra tinkamo dydžio ir reikiamą funkcijų ivairovę turintys centrai tinkamose vietose. Straipsnyje siekiama atskleisti kai kurias su Vilniaus miesto lokalių centrų vieta ir vaidmeniu susijusias problemas. Straipsnio tikslas yra pristatyti stažuotės įmonejje „Space Syntax Limited“ metu atlikto Vilniaus urbanistinès struktūros tyrimo rezultatus. Space syntax (erdvės sintaksė) yra miesto viešujų erdvių tyrimo metodika, taikoma architektūros, urbanistinio projektavimo ir planavimo veikloje. Metodika paremta urbanistinès erdvès sandaros ir jos elementų tarpusavio ryšių geometriniu vaizdavimu ir ja siekiama atskleisti erdvės savybių ir socialinių bei ekonominių procesų mieste sąveiką. Remiantis space syntax metodika parengtas Vilniaus miesto viešųjų erdvių pasiekiamumo modelis ir nustatytos viešųjų erdvių pasiekiamumo vertės, rodančios erdvės savybių svarbą ir ịtaką lokalių centrų formavimuisi strategiškai svarbiose vietose, jų gyvybingumui ir galimybėms plètotis. Sukurtas Vilniaus miesto modelis ir gauti rezultatai suteikia galimybę tęsti tyrimą miesto dalies ir lokalų centrą sudarančiu kvartalų lygmenyje.
\end{abstract}

Reikšminiai žodžiai: vieta, lokalūs centrai, space syntax metodika, viešųjų erdvių pasiekiamumo modelis.

\section{Ivadas}

Didmiesčiui ${ }^{1}$ yra būdinga skirtingų centrų tipų ịvairovè. Hierarchinę didmiesčio centrų sistemą sudaro pagrindinis (istorinis) miesto centras ir antriniai atskirų miesto dalių (taip pat periferiniai) bei lokalūs gyvenamųjų rajonų centrai. Straipsnyje remiamasi požiūriu, kad didmiesčio centrų hierarchija yra tiesiogiai susijusi su viešụjų erdvių - gatvių, aikščiu, alëjų ir kt. naudojimu susisiekti.

Nuo 1990 m. Lietuvos didmiesčiu lokalių centrų plètra nebuvo reguliuojama. Prekybos ir paslaugu objektų susitelkimui tam tikrose miesto dalyse didelès ittakos turejjo šie veiksniai: galimybès vykdyti komercinę veiklą sovietiniais metais suformuotuose vadinamuosiuose visuomeniniuose centruose, pritaikant esamus pastatus naujoms funkcijoms, ir plètoti pavienių

\footnotetext{
1 Didmiestis (city) - tai išplètotą centrų sistemą turintis miestas, regiono centras.
}

komercinès paskirties objektų ir stambių prekybos bei pramogų kompleksų projektus neužstatytuose sklypuose, esančiuose verslo požiūriu patraukliose vietose, pavyzdžiui, Ukmergès ir Ozo gatvèse Vilniuje. Nuo urbanistinès erdvès konfigūracijos ir žmonių judèjimo intensyvumo priklausančių plètros galimybių (potencialo) analizei nebuvo skiriama pakankamai dèmesio.

Straipsnio tikslas yra pristatyti Vilniaus urbanistinès struktūros tyrimo taikant space syntax metodiką rezultatus ${ }^{2}$. Naudojant geometrinị pasiekiamumo matavimo būdą siekta atskleisti urbanistinès erdvès savybių svarbą ir įtaką lokalių centrų formavimuisi strategiškai svarbiose vietose, ju gyvybingumui ir galimybèms plètotis.

\footnotetext{
2 Tyrimas vykdytas stažuotès ịmonèje „Space Syntax Limited“ metu, $2010 \mathrm{~m}$. pavasarị. Stažuotei ir moksliniams tyrimams gauta parama pagal Mokymosi visą gyvenimą/ERASMUS programą.
} 
Planuojant tyrimą buvo iškelti šie uždaviniai:

1. Parengti Vilniaus miesto viešųjų erdvių pasiekiamumo modeli.

2. Nustatyti viešųjų erdvių pasiekiamumo vertes, pateikti modeli grafiškai, naudojant raudonos bei mèlynos spalvų skalę (taikant įvairius pasiekiamumo spindulius) ir pasirinkti variantus, geriausiai atspindinčius analizės rezultatus.

3. Išnagrinèti Vilniaus miesto viešųjų erdvių sistemos ypatumus, ivertinti esamus centrus ir juos supanti kontekstą bei nustatyti galimas vietas naujiems lokaliems centrams formuoti(s).

Vilniaus miesto modeliui ir schemoms rengti naudota Lietuvos Respublikos teritorijos georeferencinio pagrindo duomenų bazès informacija, apdorota MapInfo kompiuterine programa ir Londono universiteto koledžo mokslininkų sukurta Depthmap programine įranga.

\section{Space syntax metodika}

Space syntax (erdvès sintaksè) yra miesto viešųjų erdviu tyrimo metodika, taikoma architektūros, urbanistinio projektavimo ir planavimo veikloje. Metodika paremta urbanistinès erdves sandaros ir jos elementu tarpusavio ryšiu geometriniu vaizdavimu ir ja siekiama atskleisti erdvès savybių ir socialinių bei ekonominių procesų mieste sąveiką. Šios metodikos teorinis pagrindas - fundamentalieji ir taikomieji erdvès sandaros ir žmonių judejjimo pobūdžio (pattern of movement) priklausomybès nuo urbanistinès erdvès konfigūracijos (spatial configuration) tyrimai, kurie yra paremti judejimo ekonomikos (movement economy) modeliu ir kurie nuo XX a. 8-ojo dešimtmečio pabaigos plètojami Bill Hillier $(1999 ; 2007)$ ir kitu Londono universiteto koledžo (University College London) mokslininkų (Hillier, Hanson 1984; Hillier et al. 1993; Batty 2004; Chiaradia et al. 2009). Vienas iš metodikos kūrimo tikslų yra padèti architektams suprasti formuojamos erdvè įtaką socialinei ir ekonominei veiklai, vertinant architektūrinių ir urbanistinių sprendimų poveikį, numatant gretimų kvartalų ar viso miesto urbanistinès struktūros pokyčius.

Pasiekiamumas (accessibility) apibrèžiamas kaip patogumas pasiekti tam tikrą vietą ir gali būti apibūdinamas vertinant pesčiųjų bei automobilių transporto judejjimą, atstumą pèsčiomis iki viešojo transporto stotelių ir būtiniausių paslaugų, kelionès laiką arba gyventojų pasiskirstymą tam tikroje teritorijoje (Cowan 2005). Kaip vieni iš svarbiausių pasiekiamumo vertinimo kriterijų įvardijamas laikas, sugaištas norint pasiekti kasdienes paslaugas ir epizodiškai lankomus objektus, ir tam reikalingos išlaidos. Urbanistinès struktūros funkcionavimo efektyvumą siūloma įvertinti analizuojant ne tik kelionès išlaidas, tačiau ir kainą, kurią gyventojai moka už susisiekimo infrastruktūros plètojimą, viešojo transporto eksploatavimą, lengvojo automobilio išlaikymą, nuostolius dèl kelionèms sugaišto laiko ir pan. (Juškevičius, Valeika 2007). Visi išvardinti pasiekiamumo matavimo būdai nèra tinkami nuo viso miesto struktūros pereinant $\mathfrak{i}$ detalų urbanistinès erdvés lygmeni, siekiant pagrịsti konkrečios gatvès atkarpos tarp sankryžų galimybes būti kelionès tikslu arba maršruto dalimi. Space syntax nuo kitų metodikų skiriasi tuo, kad pasiekiamumas matuojamas naudojant geometrini gatvių modelị ir vertinant mažiausio posūkio kampo (least angle) tarp dviejų gatvės atkarpų reikšmes (Batty 2009).

Viešųjų erdvių pasiekiamumo modelis (spatial accessibility model) paprastai yra kuriamas miesto topografiniame plane brěžiant ašines linijas - nagrinëjamos teritorijos viešąsias erdves kertančias vizualines (arba netrukdomo judejjimo) ašis. Vietoje ašinių linijų plano (axial map) gali būti naudojamas linijinių elementų (gatvès atkarpų tarp sankryžų) planas (segment map), kuris sudaromas automatiniu būdu, supaprastinus georeferencinio pagrindo duomenų bazès ašines gatvių linijas (Turner 2007). Susikertančių ašinių linijų arba linijinių elementų modelis naudojamas apskaičiuojant viešųjų erdvių pasiekiamumo vertes (spatial accessibility values), rodančias kelionès maršruto sudètingumą, t. y. keliomis linijomis reikia pasinaudoti keliaujantiesiems, norint pasiekti kiekvieną kitą plano liniją. Linija, kuri yra lengvai pasiekiama kitų linijų atžvilgiu, bus dažniau pasirenkama keliaujančiųjų. Didesne tikimybé, kad geriau pasiekiama linija bus ir kelionès tikslas (judejjimas ị objektą konkrečioje linijoje, to-movement), ir kelionès tarp kitų linijų dalis (judejimas linija, kai objektas yra kitoje linijoje, through-movement). Viena iš linijų verčiu yra vadinamoji integracija (integration) arba matematinis artimumas (closeness), t. y. kaip arti konkreti linija yra kitų linijų atžvilgiu. Taip pat nustatoma pasirinkimo (choice) verte arba matematinis pereinamumas (betweenness), t. y. kiek trumpiausių maršrutų driekiasi konkrečia linija tarp kitų dviejų linijų nagrinejjamame modelyje (Hillier 2007). Integracijos vertė naudojama siekiant nustatyti linijos kaip kelionès tikslo (destination) galimybes (potencialą), pasirinkimo vertè - linijos kaip kelionès maršruto tarp kitų linijų dalies (transition) galimybes (potencialą).

Naudojant linijinių elementų modeli, viešųjų erdvių pasiekiamumo vertès apskaičiuojamos atsižvelgiant i nagrinëjamą lygmenį ir pasirinktą pasiekiamumo spin- 
dulį. Sudètingiems urbanistinès erdvès sandaros bei jos elementų tarpusavio ryšiams pavaizduoti pasitelkiami matematinio ir grafinio modeliavimo įrankiai. Vienas iš svarbiausių urbanistinès struktūros elementų - gatvių ir kitų viešųjų erdvių tinklas - pateikiamas grafiškai, naudojant raudonos ir mèlynos spalvų skalę. Tai suteikia galimybę išryškinti tarpusavyje sujungtus ivairių lygmenų centrus ir subcentrus, kurių fone lieka gyvenamųjų kvartalų viešosios erdvès (Hillier 2009).

Space syntax metodika taikoma nagrinejjant įvairius urbanistinio projektavimo ir strateginio planavimo klausimus, sprendžiant urbanistinès struktūros ir jos funkcionavimo problemas: pėsčiųjų judèjimo, užstatymo tankumo, prekybos ir paslaugų funkcijų susitelkimo bei sąryšio su gyvenamąja funkcija ${ }^{3}$. Šiame straipsnyje, remiantis atlikto viešųjų erdvių pasiekiamumo tyrimo duomenimis, siekiama atskleisti kai kurias su Vilniaus miesto lokaliu centru vieta ir vaidmeniu susijusias problemas.

\section{Vilniaus urbanistinès struktūros tyrimas taikant space syntax metodiką}

Viena iš svarbiausių tyrimo naujovių yra ta, kad siekta nagrinèti ne atskirų centrų, kurie dažniausiai jungiami į per daug supaprastintą miesto modelį, urbanistinès erdvés savybes, bet atskleisti lokalių centrų tarpusavio sąveiką, t. y. jų vietą ir vaidmenị miesto viešųjų erdvių sistemoje. Lokalių centrų vietos svarbą galima paaiškinti remiantis esminiu space syntax metodikos požiūriu ị miestą, kai teikiama pirmenybè urbanistinių erdvių tinklui ir jo formavimosi procesui, kuris yra vienas iš svarbiausių veiksnių, lemiančių miesto išskirtinumą. Kadangi žmonių judejjimo srautų susitelkimas priklauso nuo susiklosčiusio gatvių tinklo, tai lemia ir funkcijų pasiskirstymą mieste. Aktyviai veiklai, pavyzdžiui, prekybai, yra ypač svarbi vieta, kurioje vyktų intensyvus judejiimas, o panašios veiklos telkiniai sudaro sujungtus ịvairių lygmenų centrus ir subcentrus. Pastarųjų fone lieka ramesnès viešosios erdvès, kuriose vyrauja gyvenamoji funkcija.

Tačiau reikia pabrèžti, kad tyrimo rezultatai neturètų būti absoliutinami, nes dèmesys yra sutelkiamas ¡ lokalių centrų galimybes (potencialą), priklausančias nuo viešųjų erdvių konfigūracijos (išsidèstymo plane ir tarpusavio ryšių) ir natūralaus, nepaveikto šalutinių veiksnių judejjimo (natural movement) centrą

\footnotetext{
3 Viešųjų erdvių pasiekiamumo modeliai sukurti ir taikomi sprendžiant ịvairių miestų urbanistinès struktūros bei jos funkcionavimo problemas, pavyzdžiui, Londono, Miuncheno, Barselonos, taip pat kaimyninių Rygos ir Talino.
}

kertančiomis gatvėmis ir pėsčiųjų takais. Kiti svarbūs aspektai, kurie nèra nagrinejjami šiame straipsnyje, tai gyventojų skaičius (tankumas), funkcijų ịvairovè ir pasiskirstymas, centro kaip traukos objekto (attractor) galimybès (potencialas) ir kiti socialiniai bei ekonominiai veiksniai.

Nagrinejjant Vilniaus urbanistinès struktūros modelị buvo remiamasi naujausiais tyrimais (Hillier 2009), kuriais siekiama įrodyti, kad centrų formavimąsi lemia lokalių ir globalių urbanistinès erdvès savybių sutapimas. Tikrinant šią prielaidą buvo taikyti ịvairūs pasiekiamumo spinduliai: $400,800,1200,1600$, $2000,5000 \mathrm{~m}$ ir begalybè - nuo lokalaus iki globalaus lygmens.

Šiame straipsnyje pristatomos pasirinkimo (choice) arba matematinio pereinamumo (betweenness) skaičiavimais pagrịstos Vilniaus miesto schemos, kurios objektyviai apibūdina nagrinejjamą dalyką. Pirmosios dvi vaizduoja viešųjų erdvių pasiekiamumą $800 \mathrm{~m}$ ir $2000 \mathrm{~m}$ spinduliu (1 ir 2 pav.), trečioji - bet kokiu (neapibrèžtu) spinduliu, vadinamuoju radius $n, \operatorname{kur} n-$ begalybè (3 pav.).

Kelionès iki $800 \mathrm{~m}$ atstumu, kurių trukmè iki 10 minučių, yra glaudžiai susijusios su miesto lokaliais centrais ir žmoniu judejimu juose - tą rodo tyrimai, kuriuos atliekant buvo nustatytas viešųjų erdvių pasiekiamumo verčių ir pèsčiųjų skaičiaus tam tikrose gatvių atkarpose atitikimas (Hillier et al. 1993). Iki $2000 \mathrm{~m}$ atstumu nutolusius centrus patogu pasiekti dviračiu arba viešuoju transportu. Viešųjų erdvių pasiekiamumo $800 \mathrm{~m}$ spinduliu schemoje (1 pav.) išryškinti ịvairių lygmenų lokalūs centrai ir galimos vietos naujiems centrams formuotis (raudonos ir geltonos spalvų skalè). Likusią didesniąją schemos dalị užima gatvių tinklas, kuriame vyrauja gyvenamoji funkcija (žalios ir mèlynos spalvų skalè). Antrojoje schemoje (2 pav.) išryškèja likusieji centrai, kurių užuomazgos pastebimos pasiekiamumo $800 \mathrm{~m}$ spinduliu schemoje.

Viešųjų erdvių pasiekiamumo neapibrèžtu spinduliu (radius $n$ ) schema (3 pav.) vaizduoja susisiekimo linijų, kuriose yra susitelkę aktyvios socialinès ir ekonominès veiklos židiniai, hierarchiją. Šioje strateginio lygmens analizės schemoje išryškintos svarbiausios (viso miesto mastu) gatvès, kuriomis galima kirsti miestą. Schemoje pakankamai tiksliai atspindèta esama būklè, išskyrus kai kuriuos nukrypimus miesto pakraščiuose $e^{4}$.

\footnotetext{
4 Vienas iš space syntax metodikos trūkumų - vadinamasis pakraščio efektas (edge effect), kai nagrinejamos teritorijos pakraščiai vaizduojami netiksliai. Norint išvengti šios neatitikties esamai būklei, reikètų išplèsti modelį prijungiant apie $2 \mathrm{~km}$ pločio priemiesčio juostą.
} 


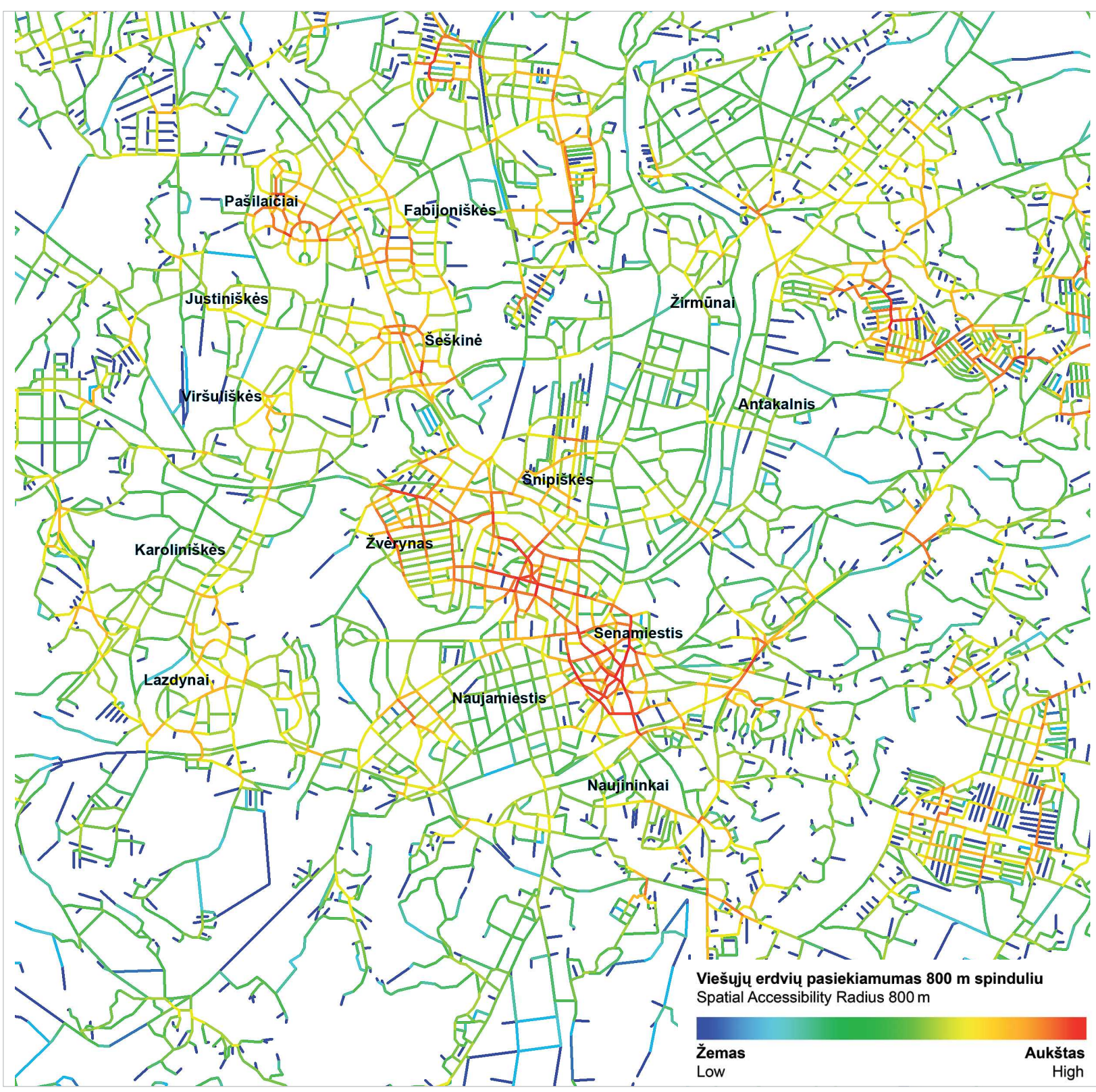

1 pav. Vilniaus miesto viešųjų erdvių pasiekiamumo $800 \mathrm{~m}$ spinduliu schema (through-movement)

Fig. 1. Spatial accessibility model of Vilnius city at an $800 \mathrm{~m}$ radius (through-movement)

Vilniaus centrinèje dalyje ${ }^{5}$ esančių lokalių centrų potencialas priklauso nuo jų ryšių su Pilies gatve ir Gedimino prospektu, svarbiausiomis miesto viešosiomis erdvèmis, kurių pasiekiamumo vertès yra aukščiausios. Pagrindinè naujojo miesto centro dešiniajame Neries krante viešoji erdvė, Konstitucijos prospektas,

\footnotetext{
5 Centrinę, vidurinę ir periferinę Vilniaus miesto dalis apibūdina jų funkcionavimo ypatumai ir savitumas (Juškevičius, Valeika 2007).
}

naudojama atvykstančiųjų i miestą iš vakarų ir šiaurès vakarų pusès, tačiau pasiekiamumo lokaliame lygmenyje atžvilgiu Baltojo ir Žaliojo tilto ašys, kaip jungtys su istoriniu centru, yra svarbesnès. İ šiaurę nuo Konstitucijos prospekto besidriekiančių lygiagrečių Giedraičių ir Kalvarijų gatvių vaidmuo skirtingas: Giedraičių gatvès reikšmè yra lokali, Kalvarijų gatvė yra svarbi šiaurès-pietų susisiekimo arterija (viso miesto mastu). Kernavès gatvès, trečiosios lygiagretès, reikšmè mažesnè. Tačiau ateityje taptų aktuali jos jungtis 


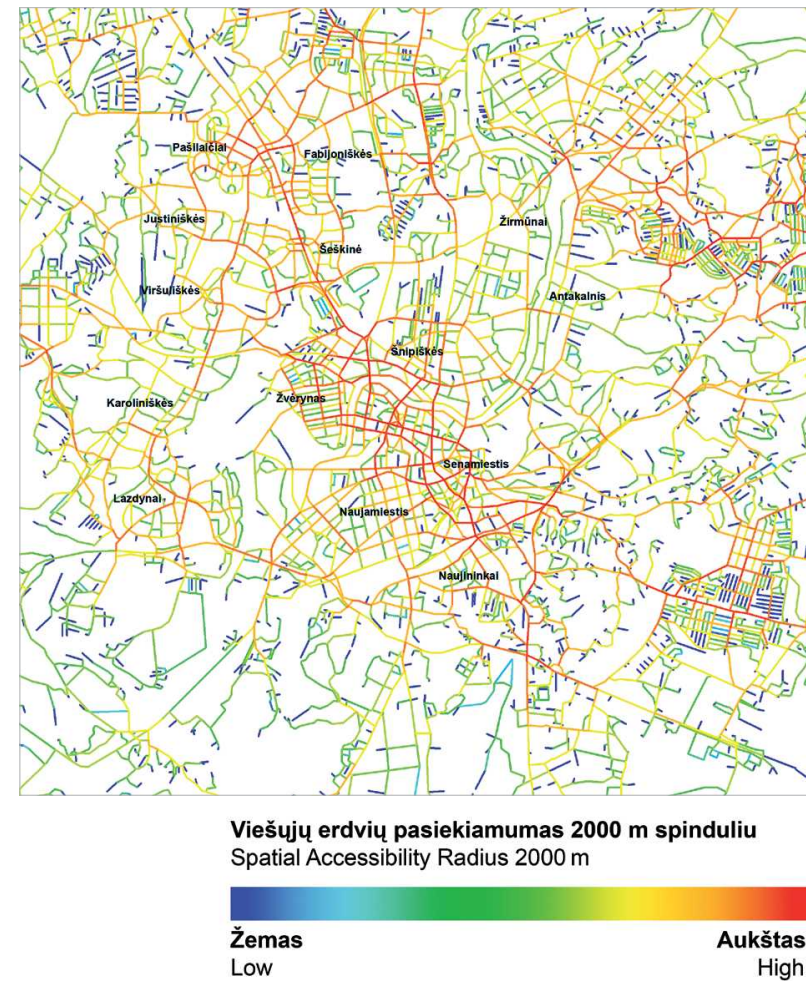

2 pav. Vilniaus miesto viešujų erdvių pasiekiamumo $2000 \mathrm{~m}$ spinduliu schema (through-movement)

Fig. 2. Spatial accessibility model of Vilnius city at a $2000 \mathrm{~m}$ radius (through-movement)

su Žalgirio gatve, kurioje pastatyti ir suplanuoti nauji komercinès paskirties objektai.

Žalgirio gatvès urbanistinès erdvès konfigūracija pasižymi savybe, kuri išskiria šią svarbią vakarų-rytų jungț iš supančio konteksto. Lokalių centrų savitumas, pastebètas nagrinëjant urbanistinès erdvès konfigūraciją (Hillier 1999; Chiaradia et al. 2009), yra tankesnis viešųjų erdvių tinklas, ši ypatybė dar vadinama pralaidumu (permeability) arba gat vių tinklo „susisiekiamumu“. Minèta ypatybè rodo galimybes pereiti, kirsticentrą ịvairiais maršrutais. Tiriant Vilniaus viešųjų erdvių tinklą, nepastebèta ryškių pasikeitimų, dèl kurių esami lokalūs centrai išsiskirtų iš juos supančio konteksto. Vilniaus centrinèje dalyje tankiausias yra senamiesčio viešųjų erdvių tinklas. Aukštesnis pralaidumo rodiklis (priklausantis nuo gatvių tinklo smulkumo) yra Žvèryne, abipus Sèlių gatvès, ypač prie sankryžos su Kęstučio gatve. Šis lokalus centras turi galimybes plètotis suformavus Sèlių gatvès išklotinę (užstatymą) buvusiame viešojo transporto mazge. Lokaliame lygmenyje ši vieta yra geriau pasiekiama negu prie Saltoniškių ir T. Narbuto gatvių sankryžos esantis prekybos ir pra-

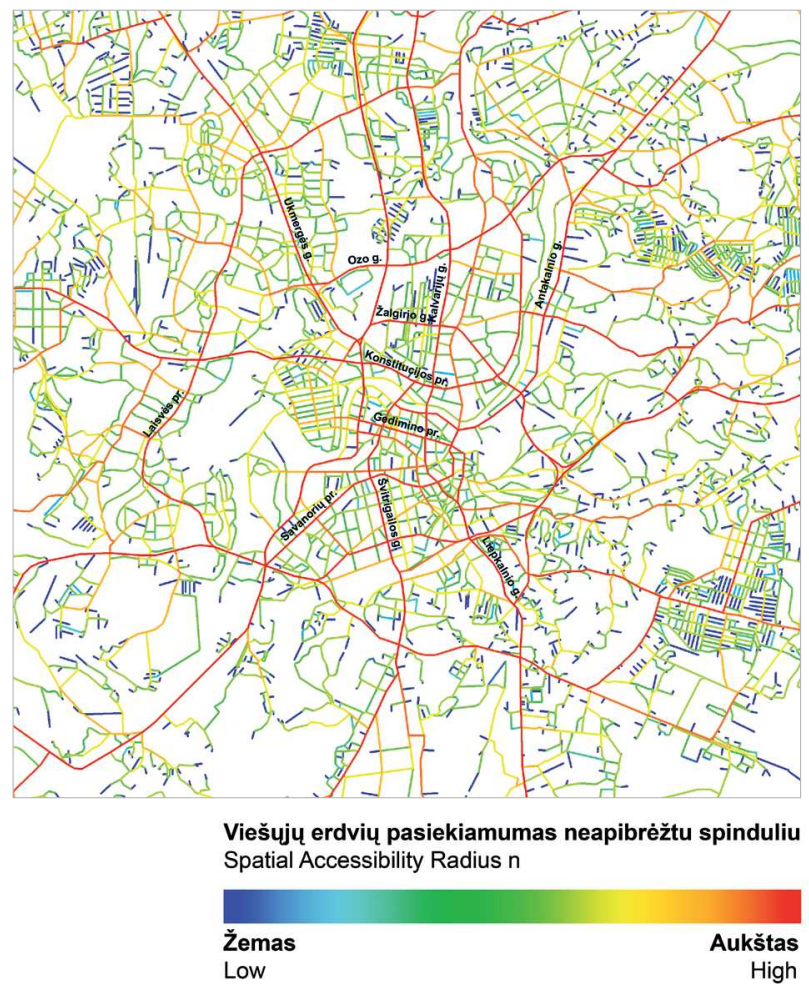

3 pav. Vilniaus miesto viešųjų erdvių pasiekiamumo neapibrèžtu spinduliu schema (through-movement)

Fig. 3. Spatial accessibility model of Vilnius city at a radius $\mathrm{n}$ (through-movement)

mogų kompleksas, kurị nuo Žvėryno rajono pietinès dalies skiria magistralinè gatvè.

Vidurinëje dalyje sovietiniais metais suformuotų gyvenamųjų rajonų ypatybe - retas gatvių tinklas ir pakankamai tankus pėsčiųjų takų, vedančių i lokalų centrą, tinklas. Kita aktuali problema nustatant tinkamiausias vietas lokaliems centrams plètoti - viešųjų ir privačių erdvių susipynimas. Pavyzdžiui, Vilniaus vakarineje dalyje vienintelè globaliu mastu reikšminga jungtis yra Laisvès prospektas, kuriame sutelktas automobilių srautas, o pèstieji dažniausiai juda šalutinèmis gatvemis ir pèsčiųjų takais kvartalų viduje. Tai turi ịtakos pasiekiamumo rodikliams. Nors gyvenamuosiuose rajonuose kasdienius poreikius tenkinantys objektai išdèstyti taip, kad būtų pasiekiami peesčiomis per 10 min., abipus Laisvès prospekto ir Ateities gatvès esantys lokalūs centrai išryškèjo tik taikant $1200 \mathrm{~m}$ ir didesnius pasiekiamumo spindulius. Panaši padètis yra Šiaurès mietelyje ir Žirmūnuose. Nors ir keista, bet Antakalnio gatveje taip pat sunku išskirti vietas, kurios būtų patogiai pasiekiamos taikant $800 \mathrm{~m}$ spinduli. Tačiau galima pastebèti, kad Žirmūnų ir Šilo tiltų prieigos turètų būti 
dažniausiai pasirenkamos keliaujančiųjų. Dar viena vieta, išsiskirianti geresniu pasiekiamumu ir tinkama naujam centrui plètoti, yra viešojo transporto mazgas Nemenčinès plento pradžioje. Neiškilo sunkumų nustatant Savanorių prospekto (atkarpoje tarp Žemaitès ir Gerosios Vilties gatvių), Baltupių, Jeruzalès (Kalvarijų gatvės atkarpose) lokalius centrus, kurie yra tinkamose vietose ir turi galimybes plètotis.

Galimos vietos naujiems lokaliems centrams formuoti yra prie svarbių magistralinių gatvių esančios pramonès ir kitos neefektyviai naudojamos teritorijos, kurias ketinama pertvarkyti i daugiafunkcius gyvenamosios ir komercinès paskirties kvartalus (pavyzdžiui, Savanorių prospekto žiedas ir Zarasų bei Subačiaus gatvių transporto mazgas).

Centrai efektyviai funkcionuoja tik išsidèstę tam tikrais atstumais vienas nuo kito. Jų tarpusavio sąveika yra svarbus aspektas, vertinant konkretaus centro galimybes plètotis. Viena iš priežasčių, kodèl lokalus centras nesiplečia ir jo įtaka mažẻja, yra ta, kad greta esantis kitas aktyvus urbanistinis mazgas pritraukia dalị potencialių centro lankytojų. Skirtingo lygmens centrų sąveiką Vilniaus mieste galima iliustruoti vidurinejje dalyje, abipus Ukmergès gatvès, esančių lokalių centrų pavyzdžiais.

Šeškinès centro gyvybingumą ir patrauklumą lankytojams galima būtų paaiškinti tuo, kad jo integracijos ir pasirinkimo - galimybès būti kelionès tikslu arba maršruto dalimi - rodikliai yra aukšti, t. y. jo vieta yra svarbi ir viso miesto mastu, ir aplink esančiu viešųjų erdvių kontekste. Abipus magistralinès gatvès išplètotas lokalus centras yra gerai pasiekiamas pèsčiomis, tačiau dali Šeškinès gyventojų, ypač turinčių lengvąji automobilị ir retai besinaudojančių viešuoju transportu, pritraukia Ozo gatveje išsidèstę prekybos ir pramogų kompleksai. Viešųjų erdvių pasiekiamumo $800 \mathrm{~m}$ spinduliu analizès schemoje galima pastebèti labai silpnus Ozo gatveje išsidèsčiusių prekybos ir pramogų kompleksų ryšius su juos supančiu kontekstu. Nors žvelgiant globaliu mastu šie objektai yra strategiškai svarbiose vietose, lokaliame kontekste jungiamumo su aplink esančių gyvenamųjų kvartalų viešųjų erdvių tinklu rodiklis yra žemas.

Fabijoniškių rajone, kur šiuo metu yra susiformavę keletas lokalių centrų (kai kurie tik pradejję formuotis), galima pastebėti suplanuotų funkcijų ir esamos struktūros galimybių neatitikimą. Rajono viduryje, tarp Fabijoniškių ir S. Stanevičiaus gatvių, esančio centro pasiekiamumo rodikliai aukščiausi taikant 400 ir $800 \mathrm{~m}$ spindulius. Didinant pasiekiamumo spinduli, nagrinejjamo centro reikšmè tolygiai mažejo, kol visiškai sumenko globaliame lygmenyje (taikant radius $n$ ). Tai yra viena iš svarbiausių priežasčių, kodèl pastaruoju metu Ukmergès ir S. Stanevičiaus gatvèse susiformavo nauji lokalūs centrai, kurie yra geriau pasiekiami viso miesto mastu. Panašūs lokalių centrų vaidmens pokyčiai vyko Pašilaičiuose, kur šiuo metu dauguma prekybos ir paslaugų funkcijų yra susitelkę prie Ukmergès gatvès ir Laisvès prospekto sankirtos.

Periferinèje dalyje esančių viešųjų erdvių pasiekiamumo rodikliai yra netikslūs dèl vadinamojo pakraščio efekto (edge effect), tačiau galima preliminariai ivvertinti ir išskirti kai kurias potencialias vietas lokaliems centrams formuotis. Tai Pilaitè (vieta turi būti tikslinama atsižvelgiant ị gyvenamųjų kvartalų plètrą), Balsiai (Žaliųjų Ežerų gatves atkarpoje), Liepkalnis (Liepkalnio gatveje ir Minsko plento pradžioje). Naujosios Vilnios, Grigiškių ir kitų nutolusių lokalių centrų plètros galimybės priklausytų nuo urbanistinès struktūros pokyčių lokaliame kontekste.

Reikètų atkreipti dèmesị ị mieste esančias sodininkų bendrijų teritorijas, kurios savaime virsta individualių gyvenamųjų namų kvartalais. Dèl tankaus gatvių, kurių pralaidumo („susisiekiamumo“) rodikliai yra netgi per aukšti, tinklo viešujų erdvių pasiekiamumo $800 \mathrm{~m}$ spinduliu schemoje išryškintos galimos vietos lokaliems centrams formuotis, tačiau dèl mažo gyventojų tankumo pasiteisintų tik šalia pagrindinių judèjimo trasų įsikūrę prekybos ir paslaugų objektų telkiniai, tenkinantys kasdienius gyventojų poreikius.

Sukurtas Vilniaus miesto modelis ir gauti rezultatai suteikia galimybę tęsti tyrimą miesto dalies ir lokalų centrą sudarančių kvartalų lygmenyje. Tiksliau apibūdinti Vilniaus miesto centrų sistemos esamą būklę padètų išsamūs empiriniai žmonių judèjimo, urbanistines struktūros funkcionavimo tyrimai ir juc rezultatu sugretinimas su parengtu modeliu. Taip pat urbanistinès analizès metu gauti duomenys gali būti naudojami vertinant miesto dalių plètros koncepcijas, esamos urbanistinès struktūros tobulinimo sprendimus, pavyzdžiui, nustatant naujas jungtis tarp lokalių centrų ir juos supančių gyvenamųjų kvartalų.

\section{Išvados}

1. Remiantis space syntax metodika parengto viešųjų erdvių pasiekiamumo modelio analizè parodè, kad pasitelkus matematinio ir grafinio modeliavimo îrankius nustatyti urbanistinès struktūros ypatumai yra glaudžiai susiję su ịvairių lygmenų centrų bei subcentrų išsidèstymu mieste ir gali būti 
objektyvus pagrindas tiriant suplanuotų funkcijų ir esamos struktūros galimybių ryšį arba neatitikimą. Ši metodika yra aktuali nagrinejjant su lokalių centrų vieta ir vaidmeniu susijusias problemas, ypač sprendžiant sovietinių metų statybos Lietuvos didmiesčių gyvenamųjų rajonų urbanistinès struktūros pertvarkymo klausimus.

2. Nagrinėjant Vilniaus centrų urbanistinès erdvès konfigūraciją, nepastebèta ryškaus viešujų erdvių tinklo sutankèjimo. Aukštesnis pralaidumo (gatvių tinklo „susisiekiamumo“) rodiklis yra Vilniaus senamiestyje, Žvèryne (abipus Sèlių gatvès) ir Žalgirio gatveje. Vidurineje dalyje sovietiniais metais suformuotų gyvenamųjų rajonų ypatybè - retas gatvių tinklas ir pakankamai tankus pėsčiųjų takų, vedančių i lokalų centrą, tinklas. Dèl šios priežasties, taip pat ir dèl viešųjų ir privačių erdvių susipynimo iškyla sunkumų nustatant tinkamiausias vietas lokaliems centrams plètoti.

3. Prielaida, kad centrų formavimąsi lemia lokalių ir globalių urbanistinès erdvès savybių sutapimas, geriausiai pasitvirtino Vilniaus centrineje dalyje (senamiestyje, Gedimino prospekte, iš dalies naujajame miesto centre ir Žvèryne). Iš sovietiniais metais suformuotų centrų aukščiausi yra Šeškinès centro pasiekiamumo rodikliai, kiti vidurinèje dalyje esantys lokalūs centrai (Ukmergès gatvès ašyje esantys Fabijoniškių ir Pašilaičių bei išsidèstę abipus Laisvès prospekto ir Ateities gatvès) taip pat yra svarbūs, bet jų urbanistinè struktūra turi būti tobulinama, gerinant pasiekiamumą lokaliame lygmenyje.

4. Atsižvelgiant ị aukštus pasiekiamumo rodiklius nustatytos vietos naujiems centrams pletoti ir esami centrai, kurie gali būti stiprinami. Reikètų išskirti Žalgirio gatvę, Zarasų ir Subačiaus gatvių transporto mazgą (centrinëje dalyje), Savanoriu prospekto žiedą ir Nemenčinès plento pradžioje esantị transporto mazgą (vidurineje dalyje). Periferinèje dalyje preliminariai galima išskirti potencialias vietas Pilaitejje (vieta turi būti tikslinama atsižvelgiant i gyvenamųjų kvartalų plètrą), Balsiuose (Žaliųjų Ežerų gatvès atkarpoje) ir Liepkalnyje (Liepkalnio gatvejje ir Minsko plento pradžioje).

\section{Literatūra}

Batty, M. 2004. A New Theory of Space Syntax [interaktyvus]. London: Centre for Advanced Spatial Analysis, University College London. 36 p. [žiūrèta 201003 26]. Prieiga per internetą: <http://www.casa.ucl.ac.uk/working_papers/ paper75.pdf $>$.
Batty, M. 2009. Notes on Accessibility [interaktyvus]. Stockholm: KTH. 4 p. [žiūrèta 201003 26]. Prieiga per internetą: <http://www.sss7.org/Proceedings/02\%20Invited\%20 Papers/I02_Batty_Notes_on_Accessibility.pdf $>$.

Chiaradia, A.; Hillier, B.; Schwander, C.; Wedderburn, M. 2009. Spatial Centrality, Economic Vitality/Viability. Compositional and Spatial Effects in Greater London [interaktyvus]. Stockholm: KTH. 19 p. [žiūrèta 201003 26]. Prieiga per internetą: <http://www.sss7.org/Proceedings/07\%20Urban\%20 Structures\%20and\%20Spatial\%20Distribution/016_ Chiaradia_Hillier_Schwander_Wedderburn.pdf $>$.

Cowan, R. 2005. The Dictionary of Urbanism. Tisbury: Streetwise Press. 468 p.

Hillier, B. 1999. Centrality as a process: accounting for attraction inequalities in deformed grids, Urban Design International [interaktyvus], 4(3): 107-127 [žiūrèta 2010 03 26]. Prieiga per internetą: <http://www.spacesyntax. com/Files/MediaFiles/Hillier_1999.pdf>.

Hillier, B. 2007. Space is the Machine [interaktyvus]. London: Space Syntax. 355 p. [žiūrèta 201003 26]. Prieiga per internetą: <http://www.spacesyntax.com/tool-links/downloads/space-is-the-machine.aspx $>$.

Hillier, B. 2009. Spatial Sustainability in Cities [interaktyvus]. Stockholm: KTH. 20 p. [žiūrèta 201003 26]. Prieiga per internetą: <http://www.sss7.org/Proceedings/01\%20Keynote\%20Papers/K01_Hillier_Spatial_Sustainability.pdf>.

Hillier, B.; Hanson, J. 1984. The Social Logic of Space. Cambridge: Cambridge University Press. 281 p. doi:10.1017/СBO9780511597237

Hillier, B.; Penn, A.; Hanson, J.; Grajewski, T.; Xu, J. 1993. Natural movement: or configuration and attraction in urban pedestrian movement, Environment and Planning B: Planning and Design [interaktyvus] 20(1): 29-66 [žiūrèta 201003 26]. Prieiga per internetą: <http://eprints.ucl. ac.uk/1398>.

Juškevičius, P.; Valeika, V. 2007. Lietuvos miestų sistemų raida. Vilnius: monografija. Vilnius. $240 \mathrm{p}$.

Turner, A. 2007. From axial to road-centre lines: a new representation for space syntax and a new model of route choice for transport network analysis, Environment and Planning B: Planning and Design [interaktyvus] 34(3): 539-555 [žiūrèta 201003 26]. Prieiga per internetą: <http://eprints. ucl.ac.uk/2092>. doi:10.1068/b32067

\section{LOCATION AND ROLE OF LOCAL CENTRES IN THE HIERARCHICAL SYSTEM OF CITY CENTRES: CASE STUDY OF VILNIUS CITY}

\section{J. Bučys}

Abstract. The most important factors, functionally diverse local centres, being in a proper location, are the ones that have an impact on urban functioning. The paper aims to reveal some issues concerning the location and role of local centres in Vilnius. The general purpose of the paper is to introduce the results of case study of the urban structure of Vilnius which were obtained during the internship at the enterprise "Space Syntax Limited". Space syntax is a method for the analysis of spatial structure used in the fields of architecture, urban design 
and planning and based on the geometrical representation of the spatial pattern. It aims to reveal the effects of spatial layout on social and economic processes in a city. Using space syntax techniques, a spatial accessibility model of Vilnius was created. The measured spatial accessibility values show the importance of spatial features to the formation of local centres in strategic locations as well as their potential vitality and viability. The model of Vilnius created and the results achieved provide for continuing the study at the level of urban blocks which constitute local centres.

Keywords: location, local centres, space syntax method, spatial accessibility model.

\section{JUSTINAS BUČYS}

Master, doctoral student (2007), Dept of Urban Design, Vilnius Gediminas Technical University (VGTU), Pylimo g. 26/Traku g. 1, 01132 Vilnius, Lithuania.E-mail: Justinas.Bucys@vgtu.lt

Master of Architecture, VGTU, 2007. Teaching: urban development projects of small towns, project of leisure centre/complex in the natural environment. Research interests: artistic dimension of urban design, methods of urban analysis, formation of city centres. 